\title{
Samiha Ayverdi Romanında Dindar ve Muhafazakâr Kadın Psikolojisi
}

\section{Selime ÖZTÜRK1}

Adem CAN2

\section{$\ddot{\mathbf{O z}}$}

\begin{abstract}
Roman sanatında kişilerin kendi gerçek psikolojileriyle var olmaları gerekir. Aksi takdirde bu kişiler tutarsız olmaktan kurtulamazlar. Kahramanların kişilik gelişiminin gerçekçi olması romanın başarısını doğrudan etkiler. Dünya edebiyatlarındaki büyük romanların önemli kahramanları psikolojik gerçeklikleriyle bilinir. Türk romanının başarılı yazarları da kahramanlarının psikolojik gerçekliğine itina göstermişlerdir. Ancak edebiyatımızda kadın psikolojisini gerçekçi bir biçimde işleyen romancı sayısı fazla değildir. Bu konuda kadın yazarlarımız daha şanslı sayılır. Samiha Ayverdi, romanlarında kadın konusuna hususi bir yer veren yazarlarımızdandır. Bu çalışma Samiha Ayverdi’nin romanlarındaki dindar ve muhafazakâr kadınların psikolojik gerçekliğini konu almaktadır. Ayverdi’nin dindar ve muhafazakâr kadın kahramanları münevver kişilerdir. Maneviyatları güçlü ve ideal tiplerdir, ananevi terbiye ile yetişmişlerdir. Bu sebeple Ayverdi’nin kendisini de temsil ettikleri söylenebilir. Samiha Ayverdi hem kadın yazar olması hem de romanlarında kadına özel bir mesuliyet yüklemesi bakımından dikkate değer bir yazardır. Onun romanlarında düz ve menfi tiplerin psikolojisini psikanalistik yöntemlerle izah etmek mümkündür. Ancak mütedeyyin ve münevver kadınların psikolojisini psikanalizmle incelemek zordur. Bunun yerine klasik İslam düşüncesindeki ilm-i nefs öğretisine müracaat edilebilir. Zira bu kadınların kişiliklerinde terbiye belirleyici bir rol oynar. Bu çalışmada Samiha Ayverdi’nin romanlarıdaki münevver kadın tipinin psikolojik gerçekliği ortaya konmaya çalışılmıştır. Bunun için hem psikanalizme hem de ilm-i nefs bilgisine müracaat edilmiştir. Ayverdi’nin hususi bir maksatla idealize ettiği söz konusu kahramanlar okurun dikkatini tasavvuf terbiyesinin insan yetiştirmekteki üstünlüğüne çekmektedir.
\end{abstract}

Anahtar sözcükler: Samiha Ayverdi, kadın psikolojisi, ilm-i nefs, roman kişisi, psikolojik gerçeklik.

\section{The Psychology of Religious-Conservative Women in The Novels of Samiha Ayverdi}

\begin{abstract}
In the art of novel, characters are supposed to exist with their true psychologies. Otherwise, they can't avoid being inconsistent. The fact that characters' personality development proceeds in a realistic way directly affects the success of a novel. The characters of great novels in world literature have real psychology. The successful authors of the Turkish Literature have likewise paid great attention to the true psychology of their characters. However, the number of novelists who depict female psychology realistically in our literature is not much. In this regard, our female authors are more fortunate. Samiha Ayverdi is one of our novelists who allocates a peculiar place to "women" in her novels. This study is about the psychological reality of religious and conservative women in Samiha Ayverdi's

Erzincan Üniversitesi, Sosyal Bilimler Enstitüsü, Türk Dili ve Edebiyatı YL Öğrencisi, selimeozt@hotmail.com. Dr. Öğr. Üyesi, Erzincan Û́niversitesi, Fen Edebiyat Fakültesi, Türk Dili ve Edebiyatı Bölümü, ademcan.ar@gmail.com, [Makale kaylt tarihi: 9.1.2018-kabul tarihi:14.4.2018]


novels. Ayverdi's devout and conservative characters are enlightened people. Their spiritualities are strong and ideal types, they have been raised by traditional training. Therefore, they represent Ayverdi herself. In terms of being a female author and appointing a special responsibility to women, Semiha Ayverdi is a notable author. It is possible to explain the psychology of the plain and the ethnic types with psychoanalytic methods in her novels. However, the psychoanalysis of religious and intellectual women is tough. Instead, it can be applied to the teaching of the knowledge of "information of identity" in the classical Islam. Because, training plays a significative role in the identities of these women. This study set out to reveal the psychological reality of the geninune female enlightened woman in Samiha Ayverdi's novels. For this, both psychoanalysis and knowledge of "information of identity" have been applied. Such characters who are idealized by Ayverdi for a particular purpose draw readers' attention to the superiority of Sufi ritual in human training.

Key words: Samiha Ayverdi, female's psychology, knowledge of self, flat character, psychological truth.

\title{
Giriş
}

Kur'ân-ı Kerîm'de bildirildiğine göre Cenâb-ı Allah; Hz. Âdem'in şahsında önce erkeği, sonra ondan kadını yaratmıştır (Karaman, ve diğerleri, 2006, s. 174). Doğurma vasfının kadına verilmiş olmasına rağmen ilk insanın erkek olması erkeğin fitratı itibariyle öncelendiğini gösterir. Zaten bu yaratma doğurma biçiminde de değildir (Saîd Havva, 1990, s. 398). Mezkûr ayet-i kerîmede kadının, erkeği teskin etmek için yaratılmış olduğunun belirtilmesi bu öncelemeye işaret ettiği kadar erkeğin de kadına ihtiyacını ifade etmektedir. Rivayete göre,

\begin{abstract}
Adem Aleyhisselam, Cennet’te oturup konuşacak bir kimse ve kendisi ile sükûnet bulacağı bir zevce bulunmaksızın tek başına gezip dolaştı̆̆ sırada Yüce Allah, ona bir uyku verdi. Uyudu. Yüce Allah, ona bir elem duyurmadan, sol eğe kemiklerinden birini alıp yerine et doldurdu. Adem Aleyhisselam daha uykudan uyanmadan, Hz. Havva’yı ondan yarattı (Köksal, 2011, s. 34).
\end{abstract}

Bu bilgiden kadının erkek için tamamlayıcı bir unsur olduğu, yani erkeğin kadınla ikmal edildiği hükmüne varmak mümkündür. Hz. Havva'nın yaratılışı Hz. Âdem'in tek başına eksikliğini gösterir, çünkü onun kendine uygun bir hayat arkadaşına ihtiyacı vardır. $\mathrm{O}$ ancak böyle bir eşle muvazenesini bulup hayatını sürdürebilir. Bu yaratılış biçimini kadının lehine veya aleyhine değerlendirmek doğru olmaz. Bahsi geçen ayetin başındaki "tek nefesten/candan halk eden" ibaresi, kadın ve erkeğin aynı cevherden yaratıldığını gösterir. Buna rağmen kadının erkekten sonra yaratılmış olması onun daima ikinci bir insan olarak görülmesine sebep olmuştur. Düşünce tarihi kadını kınayan sözlerle doludur. Alfred Adler'e göre "Kadınların aşağı olduğu fikri öyle yaygındır ki her irkta buna rastlanır." (Adler, 2014, s. 138). Hâlbuki insanın yaratılışıyla ilgili ayet ve hadislerden ancak kadının erkeğe göre hususi bir fitrata sahip olduğu neticesi çıkarılabilir. Nitekim Hz. Muhammed (SAV) bir hadis-i şerifinde, "Kadın kaburga kemiğinden yaratılmıştır. Kaburganın en eğri yeri de üst kısmıdır. Onu, doğrultmağa kalkarsan kırarsın! Hali üzere bırakırsan, eğrilikte devam eder. Kadınlar hakkında birbirinize hayır tavsiye ediniz." (Buharî, 2014, s. 115) buyurmuştur ki bu hadis kadının psikolojik hususiyetini vurgulamaktadır. Kısacası o, erkekten farklı bir psikolojiye sahiptir. Öyleyse maşeri hayatta kadın erkeğin ölçülerine göre değerlendirilemez. Dolayısıyla bilimde, fikirde ve sanatta kadından söz ederken yaratılışı itibariyle erkekten farklı özelliklerle donatılmış bir insanla karşı karşıya olduğumuzu bilmemiz gerekir. 
İnsanoğlu en eski anlatılardan beri kadından söz ederken itinalı bir dil kullanmıştır. Bu itinanın arkasında kadının hassas yaratılışını karşılama düşüncesi vardır. En eski anlatılarda bile kadın farklı bir insan olarak ele alınmıştır. Ona yüklenen vasıflar erkeğinkinden çok başkadır. O; mitten masala, destandan efsaneye, hikâyeden şiire kadar hemen bütün anlatıların cazibe merkezidir. Bu ayrıcalık edebiyatın modern türlerinde de mevcuttur. Roman sanatında kadın genellikle entrikanın ekseni ve kurgunun muharrikidir.

Roman sanatında kadınlık mümbit bir meseledir. Dünya romanında kadınla ilgili çok geniş bir literatür meydana getirilmiştir. Farklı milletlerin zenginleştirdiği bu literatürdeki bazı benzerlikler dikkate şayandır. Mesela klasik roman geleneğinin bütün dünya edebiyatlarında yaşayan kadın tipleri mevcuttur. Onları birtakım vasıflarına bakarak rahatlıkla tanıyabiliriz. Hatta bazen bunlar o edebiyatın en güçlü romanlarında yer alırlar. Öyle anlaşılıyor ki bu tiplerin temsil ettikleri kadınlık hâli pek çok milletin romanını beslemiştir. Nitekim dünya edebiyatlarının en önemli romanları genellikle kadına yeni bir bakış getirebilenlerdir. Vadikeki Zambak yazarı Balzac'ı, Madam Bovary yazarı Flaubert'i ve Toprak Ana yazarı Cengiz Aytmatov'u bu dikkatle okumak gerekir.

Romanın, kadını ele alış biçimi kendinden önceki türlerden farklıdır. Eski türlerde kadın genellikle sembolik bir varlıktır. Hâlbuki roman onu kendi fitratına uygun gerçek bir kişi olarak kurgular. Klasik roman geleneğinde bu gerçekliğin abartılmış olduğu söylenebilir. Nitekim Balzac'ın Eugénie Grandet'si ya da Henriette'i, Émile Zola'nın Jervez'i, Tolstoy'un Anna Karenina'sı, Tanpınar'in Nuran'ı birer kadınlık abidesidir. Modern romanda ise kadının bu abartıdan kurtarıldığı söylenebilir. Böylece kadın beşerî hayattaki gibi zaaf ve meziyetleriyle daha gerçekçi bir hüviyete kavuşmuştur. Ancak bu gerçekliğin arkasındaki asıl saikin psikolojik boyut olduğu belirtilmelidir.

Roman kişisi pisikolojik bir varlıktır. Bu psikoloji yaşa, cinsiyete, kültüre ve maşeri hayata göre değişir. Kadın da romana kendi psikolojisiyle girer. Onun başarılı bir roman kahramanı olması ferdî psikolojisinin doğru tespitiyle mümkündür. Yukarıda kadın ve erkeğin ontolojik olarak birbirine muhtaç olduğu belirtildi. Bu sebeple birini anlamak için diğerine bakmak şarttır. Hayatları müşterek olan bu iki insanın hayata bakışları, algıları, sezgileri, duyguları ve hayalleri birbirinden ayrıdır. Dolayısıyla kadının erkeğe göre farklı bir psikolojik gerçekliği vardır. Ondan söz ederken bu psikoloji dikkate alınmazsa onun aleyhine sonuçlara varılabilir. Öyleyse roman sanatında kadın kendine has psikolojiyle yer almalıdır.

Türk romanında kadın psikolojisi genellikle ihmal edilmiştir. "ilk romanlarımızı okurken muharrirlerinin her akşam sofralarında karı, anne, kız kardeş olarak gördükleri şeklinde bile kadını tanımadıklarına hükmedeceğimiz geliyor. Eserlerindeki kadınlar o kadar hakiki hüviyetten mahrumdurlar." (Tanpınar, 1998, s. 62). Meşrutiyet'le başlayıp Cumhuriyet'le neticelenen süreçte Türk romanı, sosyal hayattaki hızlı değişimi genellikle kadın üzerinden anlatmıştır. Hatta yozlaşmanın faturası da kadına kesilmiş gibidir. Cumhuriyetin ilk yıllarında ise kadına ideolojik bir mesuliyet yüklenir. Bundan dolayı kadın kendi trajedisiyle başbaşa kalamaz. Dönemin güçlü romanlarındaki pasifliği de bundan kaynaklanmış olmalıdır. Diğer taraftan kadın yazarların bu konuda biraz daha hassas oldukları görülür. "Reşat Nuri, hatta Yakup Kadri gibi Kemalist pozitivizmi destanlaştıran romancllarımı, Halide Edib'e nispetle birer toy sosyolog[dur].” (Özel, 2017, s. 12). Sinekli Bakkal'ın Rabia'sı İslamiyet ile Batı'yı tasavvuf potasında mezcetmeye girişir. Ancak Tanpınar'ın Nuran'ı gibi o da biraz abidevi görünür. Modern romanda kadın yüceliğini yitirerek cinsiyetiyle var olmaya başlamıştır. Modern Türk romanı da bu temayülden nasibini alır. Adalet Ağaoğlu'nun Aysel'i Kemalist ideolojiyi cinselliğiyle telif etmeye kalkışır. Hatta bunu gerçekçi kılmak için epeyce psikolojik mülahaza da 
serdedilmiştir. Tam da bu aşamada kadının ve kadınlığın millı̂ kültüre aykırı bir mecraya döküldüğünü gören bir başka kadın yazarımız Samiha Ayverdi, Türk romanında farklı bir kadın tipini öne çıarır. Ananevi terbiye ile yetişen bu kadın tipi, yazarın kendisi ve yakın çevresinden izler taşımaktadır. Söz konusu bu tipin en önemli hususiyeti mütedeyyin ve muhafazakâr olmasıdır. Fakat bu, sufi gelenekten beslenen müspet bir muhafazakârlıktır. Dolayısıyla söz konusu tipin kendine mahsus bir şahsiyeti vardır. Onu daha iyi tanımak için şahsiyetini psikoloji biliminden faydalanarak incelemeye ihtiyaç vardır.

Samiha Ayverdi'nin romanlarındaki dindar kadın tipinin psikolojisine geçmeden önce din ve psikoloji bahsine, bir başka deyişle psikoloji biliminin dine bakışına kısaca değinmek gerekir. Psikoloji biliminin kurucusu Sigmund Freud ve takipçilerinin dine bakışları menfidir. "Freud'a göre [din] bir çocukluk deneyiminin yinelenmesidir." (Fromm, 2012, s. 22). Yani bir çocuk, yaşadığı korkuyu nasıl babasına sırtını dayamak suretiyle öteliyorsa Tanrı'yı da öyle görür ve bu itikat aslında geçici bir çocukluk nevrozudur. Öyleyse yetişkin bireylerin bir an evvel bu nevrozdan, yani dinden kurtulması gerekir. Freud ateisttir ve Tanrı fikrini tamamen reddeder. Ona göre din, anne babasından ayrılan insanı kendi güvensizliğinden korumak için uydurulmuş bir yanılsamadır (Snowden, 2011, s. 153). Dahası bu yanılsama insanlık için büyük bir tehlike arz etmektedir.

Freud, dinin bir yanılsama olduğunu kanıtlama çabasının ötesine geçer. O dinin bir tehlike olduğunu çünkü dinin tarih boyunca işbirliği içinde bulunduğu çürümüş insani kurumları kutsama eğiliminde olduğunu söyler; daha da ileri giderek dinin insanlara bir yanılsamaya inanmayı öğrettiği ve eleştirel düşünceyi yasakladığı için zekânın gerilemesinden de sorumlu olduğunu belirtir. (Fromm, 2012, s. 23).

Din bir nevroz durumu ise dindar insanların, ömürleri boyunca ifa ettikleri dinî ayinler, yani ibadetler nedir? Freud bunlara da bir karşlık bulmuştur. "Nevrotiklerdeki saplantılı (obsessive) davranışlarla dinî ibadetler/ritüeller arasında benzerlikler olduğundan hareketle ibadetlerin birer saplantı nevrozu olduğunu iddia etmiştir.” (Köse, 2011, s. 66). Hülasa bu fikirlerin sahibi Freud gerçek bir pozitivisttir.

Freud'un takipçileri din karşısında onun kadar katı değildirler. Hatta dine bakışları seleflerinin aksinedir. Carl Gustav Jung’a göre "Dinsel deneyimin özü, kendimizden daha üstün güçlere boyun eğmektir.” (Fromm, 2012, s. 27). Jung ruhun varlı̆̆ını kabul eder ve din ile ruh arasında sıkı bir münasebet bulur:

Daha önce de işaret edildiği gibi Jung’a göre en basit tanımıyla ruh, bir gerçekliktir; gerçek ise etkin olandır. Din, tartışmasız olarak insan ruhunun en eski ve en yaygın ifade tarzlarından birisidir... Karşılıklı ilişki çerçevesinde ruhsal bir süreç olarak din, kişiliğin tamamını kavrar ve etkiler. (Bahadır, 2010, s. 106).

Jung bilinçaltını dindarlığın önemli bir boyutu olarak değerlendirir. Jung’a göre din, bir gücün -Tanrı ya da bilinçaltı- kontrolümüzü aşarak zihnimize zorla girmesidir. Böylece yazar dini, bilinçaltının bir ögesi hâline getirmiştir. Onun amacı dini izah etmekten ziyade bilinçaltını temellendirmektir: "Jung, dini psikanalitik bir olguya indirger ve bilinçaltını da dinsel bir olgu olarak ele alarak yüceltir." (Fromm, 2012, s. 30).

Psikanalistler, dini psikolojik bir vakıa kabul etmekle birlikte ona farklı açıklamalar getirmişlerdir. Alfred Adler, dindarlığı, yanlış anlaşılmaktan mustarip olan insanın kendini güvende hissettiği bir yere 
sığınması olarak görmektedir. Ona göre bu insanlar, "Sürekli olarak kendi kendilerine şikâyet edip dert yanarlar ve acılarını kendisiyle barışık bir Tanrı'ya havale ederler.” (Adler, 2014, s. 279). Bir başka deyişle kendi davranışlarının sorumluluğunu alamayan mütedeyyin insanlar, dine yönelerek bütün eylemlerinin kaynağını Tanrı'ya atfetmektedirler. Böylece bir savunma mekanizması olan yansıtmaya başvurarak kendi yetersizliklerini Tanrı'nın bir takdiri olarak görüp rahatlarlar. Erich Fromm ise dinî hayatın, günümüz toplumunda insanı çelişkiye sürüklediğini düşünmektedir. Ona göre kiliseye giden birey sevgi, merhamet, yardımseverlik, dürüstlük, alçakgönüllülük gibi konularda vaazlar dinlemekte; ancak gerçek hayata dâhil olduğunda vaazlarda dinlediklerinin geçerli olmadığını görerek ikilem yaşamaktadır. Fromm dini sorgularken "Mesele dinin olup olmaması değil, dinin ne tür olduğudur; din insanın gelişimine katkıda bulunup kesin bir biçimde onun gücünü açığa mı çıkarıyor, yoksa bu gücü felce mi uğratıyor?” diye sormaktadır (Fromm, 2012, s. 36).

Psikanalistlerin din tasavvurları Hristiyanlık ve Yahudilik'le ilgilidir. Bu nedenle Müslüman bir yazarın düşüncesiyle bağdaşmayabilir. Ancak roman kişilerinin psikolojileri incelenirken -itikatları farklı bile olsa- yukarıda görüşleri değerlendirilen teorisyenlerin geliştirdikleri psikanalizme müracaat etmek bir zorunluluktur. Diğer taraftan Batı tandanslı psikoloji biliminin başka dinlere mensup bireylerin psikolojilerini izahta yetersiz kalacağı açıktır. Samiha Ayverdi’nin romanlarındaki dindar kadınlar tam da böyle kişilerdir. Bundan dolayı onların psikolojilerini incelerken İslami kaynaklara da başvurmak gerekir. Ancak daha önce yazar-metin ilişkisini açıklayabilmek için romancının dindarlkk ve muhafazakârlık anlayışına kısaca yer vermek faydalı olacaktır.

\section{Samiha Ayverdi'de Dindarlık ve Muhafazakârlık}

Türkçe sözlüklerde din ve dindarlık kavramları açıkça tanımlanmıştır. Din “Tanrı'ya, doğaüstü güçlere, çeşitli kutsal varlıklara inanmayı ve tapınmayı sistemleştiren toplumsal bir kurum[dur].” (Türkçe Sözlük, 2011). Dindarlık kavramı ise dindar kelimesinden türemiş olup dinine bağlı olma, dinî vecibeleri gayretle yerine getirme anlamlarındadır. Dindarlık'n aksine muhafazakârlık kavramı tartışmalıdır. Arapça $h \imath f z$ kökünden türemiş olan muhafazakârlık kelimesinin kavram anlamı vuzuh kazanamamıştır. Sözlüklerde "millî, mânevî değerleri, âdet ve gelenekleri korumaya, olduğu gibi yaşatmaya çalışma durumu" (Kubbealtı Lugati, 2018) ile "tutucu, bir şeyi olduğu gibi, değiştirmeden tutmak isteyen, eskiye bağlı" (Devellioğlu, 2015, s. 775) anlamları arasında gider gelir. Cumhuriyet'in ilk yıllarında kelimeye dar ve menfi bir anlam yüklenmiştir. Nitekim Türkçe Sözlük'ün ilk baskısında kavrama tek kelimelik bir karşllık verilmiştir: "Tutuculuk”. (Türkçe Sözlük I, 1944, s. 417). Sonraki dönemlerde bu dar anlamından sıyrılan kelime bilimde, siyasette, dinde, sanatta, edebiyatta kısacası hemen her alanda kullanılmaya başlanmıştır. Günümüzde modernizmle birlikte hızlanan değişimi yavaşlatarak dengelediği için müspet anlamlar kazanmaya başlamıştır. Dahası gelenekle bağı sürdürmenin bir başka adı olmuştur. Geleneği devam ettiren ve geleneğe saygı duyan bilim, fikir, siyaset ve sanat adamlarına ise muhafazakâr denmeye başlanmıştır.

Samiha Ayverdi muhafazakâr olarak bilinen yazarlarımızdan biridir. Onun muhafazakârlığı geçmişi körü körüne taklit olmadığı için asla tutuculuk sayılamaz. Zaten asıl eserini verdiği roman türünün bizde geçmişi de yoktur. Tanzimat romanı Cumhuriyet romanının geçmişi sayılırsa Ayverdi romanının bu geçmişle ilgisi çok zayıftır. Ayverdi’nin muhafazakârlığı klasik terbiye, zevk ve estetiğe bağlllıktan ibarettir. O, bunları modern Türkiye için kurtarıcı birer usare olarak görür. Zira milletlerin tarihleri olduğu gibi fikir, sanat ve estetiğin de tarihi vardır. Geleneğini reddeden milletler beslenme kaynaklarını kuruttukları için tekâmül edemezler. Dolayısıyla yazar, fikir ve sanatını klasik gelenekten ilhamla ihya etmek istemektedir. 
Ayverdi'nin fikir ve sanat anlayışı din düşüncesinden bağımsız olarak ele alınamaz. Onun dine ve itikada dair düşüncelerinin esasını tefekkür ve teşekkür hâli oluşturur. Aslında bu düşünce sistemi tasavvuftur. Ayverdi'ye göre insan, ruhu itibariyle Rabb'inin bir aynasıdır; iradesine Allah'ın yön verdiği bahtiyar bir kuldur. Öyleyse bu nimetin kıymetini bilmelidir. Bu kemale ermiş insanlardan mürekkep milletler müreffeh bir hayat yaşarlar. Dolayısıyla Ayverdi toplum düzeni için dinin şart olduğuna inanır.

Ona göre Allah duygusunu kaybetmiş toplumların fertleri, nerede ve ne şartta olursa olsunlar, birbirlerine sıcak ve yumuşak bir dostlukla bağlanamazlar; belki kanunların, zaruret veya menfaatlerin baskısıyla yaklaşmaya çalışırlar fakat bu, kuru bir ortaklıktan ileri gidemez. (Demirci, 2007, s. 13).

$\mathrm{Bu}$ anlayışta din insanı korkutmaz, zorlamaz ve yormaz; sevgi ve muhabbete dayanır. Rabbin adaleti karşısında bütün insanlar eşittir. Her insan gücü nispetinde mesuliyet sahibidir. Ayverdiłye göre gerçekten iman etmiş bir birey toplum nezdinde hareket dairesine çeki düzen verir.

İman, beşer ihtiraslarını kıvama sokar. Kanun ve nizamın durduramadığı hayvanî temâyülleri kontrol eder. İşte bu iman tarih boyunca millî değerlerimizi korumuş, cemiyetin çürük ve sakat taraflarını lehimleyip perçinleyerek mütecanis/uyumlu bir bütün meydana getirmiştir. (Demirci, 2007, s. 13).

Samiha Ayverdi, İslamiyet’in sevgi ve kardeşlik umdelerini daima öne çıarır. Bu dinde insanın insana üstünlüğü ancak takva iledir. İnsan renginden, dilinden, cinsiyetinden ötürü hor ve hakir görülemez. Yazar Küplüce'deki Köşk adlı hatıratında dinî taassuba itiraz ederken "Hayır imam efendi, İslam bu değil... Ey imam efendi, ya nedir, dersen İslam, sevgi, dostluk, tasanüt, adalet, insaf, hikmet ve irfan demektir. Cemaatini, Hakk'a da halka da ancak ve ancak muhabbet köprüsünden geçirerek inandırabilirsin.” der. (Ayverdi, Küplücedeki Köşk, 2006, s. 242). Ayverdi'ye göre İslamiyet’i beşerî değerlerden ayrı düşünemeyiz. Bu dine mensup milletlerin erdeme, fazilete, hikmete, adalete, irfana ve vicdana değer vermesi gerekir. Zaman ve zemin bahane edilerek bu değerlerden vazgeçilemez. Bu değerleri yaşatan milletler üstün medeniyetler kurabilirler. Müslüman Türk milleti Selçuklu ve Osmanlı devletleri eliyle böyle bir medeniyeti inşa edebilmiştir. Öyleyse tarihî tecrübemizden ilham almamız gerekir. Tıpkı ceddimiz gibi önce dini doğru anlamalı ve doğru yaşamalıyı.

Samiha Ayverdi, Türk gelenek ve görenekleri ile Müslümanlığın yüzyıllar evvel birbirine karışmış, birbiri içinde erimiş ve birbiriyle bütünleşmiş olduğuna inanır. Gelişmenin ve ilerlemenin mevcut düzeni yıkmaktan değil, zamana göre yapmaktan geçtiği inancındadır. Ancak yaşadığı dönem itibarı ile yıkımın en acısına şahit olmuştur. Ayverdi'nin eseri esas itibariyle Müslüman Türk toplumundaki bozulmayı anlatır. Yazara göre bunun temel sebebi geleneklerimizi terk ederek bilmediğimiz iklimlere yelken açmaktır. "Bir milletin sırtında zırh olan örf ve âdetlerin birer koruyucu olduğunu, en küçük yaştan itibaren cemiyetleri bir aşı kudretiyle hariçten gelecek zararlı cereyanlara karşı korumak yolunda o milletin müdafaa silahlarından biri olduğunu ne yazık ki unuttuk.” (Ayverdi, Küplücedeki Köşk, 2006, s. 39). Yüz ylllar boyu toplumu ayakta tutan millî örf ve âdetlerin yok edilmesi milleti köksüz ve kültürsüz bırakmıştır. Müslüman Türk milleti için bundan daha büyük bir tehlike yoktur. Samiha Ayverdi’nin muhafazakârlığı millî hayatın bekasını tehlikede gören aydınların sanat ve edebiyat yoluyla millî hasletleri ihya çabasından başka bir şey değildir. "Samiha Ayverdi ve çevresi 'kökü mazide olan ati' düşüncesini savunan Yahya Kemal ekolünün takipçileridir. Bu Tanıl Bora’nın belirttiği gibi, kendini siyasal değil, kültürel düzlemde 'bir duruş ve duyuş olarak' ifade eden bir klasik muhafazakârlık olarak tanımlanabilir." (Tuzak, 2009, s. 248). Bu telakki maziyi mazi olduğu için değil, istikbali inşa için yaşatmak istemektedir. Bu manadaki muhafazakârlık beşerî tekâmüle dayandığı için değişime açıktır. 
Ancak bu değişim insanı insan yapan değerlerden feragat etmek şeklinde olamaz. Bu olsa olsa Edmund Burke'nin dediği gibi "muhafazakâr reform” biçimidir (Burke, 2017, s. 63). İnsanı mazisiyle birlikte kendisinden uzaklaştırmaz. Ayverdi'nin romanı tam da bu felakete işaret etmektedir. Onun romanlarındaki münevverler, maziden devraldıkları fazilet ve irfanı her şeye rağmen hâlde yaşatmaya çalışırlar. Bu mesuliyeti üstlenmiş kadın kahramanlar ise Cumhuriyet Dönemi Türk romanı için hususi bir yaklaşımdır.

\section{Samiha Ayverdi’nin Romanlarındaki Dindar, Muhafazakâr ve Münevver Kadın Tipi}

Samiha Ayverdi'ye göre münevver kadın, dindar ve müspet manada muhafazakâr kadındır. Onun romanlarındaki münevver kadınlar maneviyatı güçlü, ideal tiplerdir. Klasik zevk ve terbiyeyle yetişmiş bu kadınlar, son derece ağırbaşlı ve kâmile insanlardır. Bu kadınların meziyetlerini tebarüz ettirmek isteyen yazar, onları genellikle etrafındaki dejenere tiplerle çatışma hâlinde kurgulamıştır. Bu çatışmada münevver kadın ahlaki seciyesiyle yücelirken karşıt tip benliğini ve haysiyetini kaybetmeye mahkûm olur. Yazar böylece hem Tanzimat'tan beri kendi benliğine yabancılaşan Türk toplumunda iffetini kaybeden kadının ne büyük bir tehlike olduğunu göstermiş hem de geleceğin Müslüman Türk toplumunu inşa etmede mütedeyyin ve münevver kadının rolünü belirtmiş olur.

Ayverdi’nin romanlarındaki münevver kadınlar yaşadıkları dönemin müstesna kişileridir. Ancak yazar, onları zamanın dışında kalmış bireyler olarak görmez. Hatta bu zarif ve kültürlü kadınlar az çok yazarın kendisini de temsil ederler. Dahası, Ayverdi'nin dâhil olduğu muhitlerde yakından tanıdığı gerçek kişilerden izler taşımaktadırlar. İnsan ve Şeytan yazarı, Türk toplumunun ahlaki çöküşe uğradığı ve kadınının hüviyetini kaybettiği bir dönemde okurlarının huzuruna güçlü bir kadın tipiyle çıkmıştır. Onları güçlü kılan hususiyet itikatlarıdır. Samiha Ayverdi’nin dindar-münevver kadınları kendini gerçekleştirmiş bireylerdir. Ruh sağlıkları yerinde olan bu kişiler herhangi bir yetersizlik hissine kapılmazlar. Erkeğin karşısında değil, yanında yer alırlar. Tasavvuf terbiyesiyle yetiştiklerinden geniş bir hoşgörüye sahip, edepli ve sakindirler. Zorluklarla yüzleşmekten kaçınmayan, onları aşmak için makul çözümler arayan; hayatla, çevreleriyle ve kendileriyle barışık huzurlu insanlardır.

Genel bir değerlendirmeyle Ayverdi'nin romanlarındaki münevver kadın kahramanlara ait benlik algısının, Maslow'un ihtiyaçlar hiyerarşisi adını verdiği teorisindeki kendini gerçekleştirme basamağına denk düştüğü söylenebilir. Ancak dindar ve muhafazakâr olan bu kadınları sadece psikanalizmin verileriyle tanımak mümkün değildir. Bunun için tasavvuf erbabının seyr-i sülukûnu anlatan ilm-i nefs epistemolojisine de müracaat edilmelidir. Zaten yazar, dine nevrotik bir hastalık nazarıyla bakan psikanalistlerle uyuşmaz. Ona göre din insanın akli tercihidir ve bireyin kişilik gelişimi onunla tamamlanır. İnsanı tanımak için itikadını bilmek gerekir. Bu nedenle yazarın münevver kadın tipleri tahlil edilirken hem psikoloji biliminin verileri hem de ilm-i nefs bilgisi birlikte değerlendirilecektir.

\section{Samiha Ayverdi’nin Romanlarındaki Münevver Kadın Tipinin Psikolojik Gerçekliği}

Samiha Ayverdi’nin neredeyse bütün romanlarında idealize edilmiş münevver bir kadın tipi mevcuttur. Ancak bu tip günümüz ölçeğinde yükseköğrenim görmüş, belli alanlarda ihtisas yapmış kişilerden farklıdır. O, genellikle bir mürşidin manevi terbiyesinde yetişmiş olgun insandır. Samiha Ayverdi'de münevverliğin/aydınlı̆̆ın/entelektüelliğin ölçüsü tasavvuf terbiyesidir. Yazara göre toplumu yönlendirebilecek güce sahip ideal kadın tasavvuf terbiyesi almış kadındır, o bu terbiyeyle hem muhafazakâr hem mütedeyyin hem de münevverdir. 
Batmayan Gün'de Aliye diğer kadın karakterlerden üstündür ve onlar üzerinde hâkimiyet kurmuştur. Dedesi İrfan Paşa'nın mana âlemine yolculuğunu anlattığı not defterlerini okuyarak bir arayışa başlayan, annesinden ve içinde bulunduğu yozlaşmış ortamdan uzaklaşmak için yurt dışına okumaya giden ve burada aradığına vasıl olan entelektüel bir kişidir. İstediğine kavuşması kolay olmamıştır. Bunun için senelerce araması, vardığı duraklarda kararsız kalması ve psikolojik bunalımlar geçirmesi icap etmiştir. Nihayet erdiği saadet, çektiği çilenin karşllı̆̆ıdır. Denilebilir ki Aliye mürşidini arayan mürit gibidir. Karşılaştı̆̆ bütün badireleri atlatmadan vuslata erememiştir. Ayverdi'nin romanlarındaki münevver kadınlar, ya buhran içinde dönüşüm geçirerek olgunlaşırlar ya da nefis terbiyesiyle kemâle ererler. Batmayan Gün'ün Aliye'si, dedesinin defterleri vasıtasıyla yola düşmüştür. Yol bir vasıtadır, bu yolda mürşitsiz kemal olmaz:

\begin{abstract}
"Benim vasıtaya ihtiyacım yok demek" hatasına düşme, yüzünü görmek için aynaya, içini görmek için röntgen ışınlarına, ilim, musiki ve sanat öğrenmek için birer hocaya ihtiyacı olan aciz bir insan, birlik esrarını görmek, manasını, hakikatini bulmak için neden bir öğreticiye muhtaç olmasın? (Ayverdi, 2010, s. 191).
\end{abstract}

Aliye’nin mürşidi Prof. Kerim Bey'dir. Kerim Bey kemal ehli bir insandır. Samiha Ayverdi, onu tanıdı̆̆ı kişilerden hareketle kurgulamış olmalıdır. Zira yazarın, Ümm-i Ken'an Dergâhı şeyhi Ken'an Rifai'nin manevi terbiyesini aldığı ve sanatında bu terbiyenin derin bir tesiri olduğu bilinmektedir. Binaenaleyh romancının hemen her eserinde Ken'an Rifai'nin temsilcisi olan bir veya birkaç kişi yer alır. Batmayan Gün'de de Rifai'nin temsilcisi olarak görünen iki kişiden biri Aliye'nin dedesi İrfan Paşa, diğeri Prof. Kerim Bey'dir. Kerim Bey, Rifai'nin gençlik yıllarını; İrfan Paşa ise yetişkinlik dönemini yansıtmaktadır.

Kendisinden yaşça büyük ve evli olan Kerim Bey'e bağlanarak ilahî aşka ulaşan Aliye'yi ve onun hislerini tasavvuf öğretisini dikkate almadan anlamak zordur. Zira bu öğretide insan hayatın sırrına talip olur ve bu sırra vâkıf olmak akılla değildir. Ayverdi bunu "O esrarı akılla bilmeye çalışma, çünkü akıl da mahlûk olduğundan, bilgisi kendi gibi mahlûk olan şeylerin hududunu aşamaz.” (Ayverdi, 2010, s. 191) diyerek açıç̧a belirtir. Dolayısıyla buna talip olan Aliye'nin davranışlarını psikoloji bilimiyle izah etmek imkânsızdır. Çünkü Freud'un, yaşamın amacını cinselliğe indirgeyen libido kavramı bunun için yetersiz kalır. Freud'a göre insan psikolojik gelişimini çocukluk çağında tamamlar ve bundan sonra yaşadığı nevrozların sebebi çocuklukta olgunlaşmamış psişik etmenlerdir. Ayverdi ise insan tekâmülünün sürekli olduğunu düşünür. Hatta ölüm bile bunun için bir son sayılmaz. Çünkü insanın vasıl olmak istediği bir sırrı/aşkı vardır. Ona layı olması için ömür boyu çaba sarf etmesi gerekir. Bu aşkın cinsellikle ve cinsel hazla hiçbir ilgisi yoktur. Öyleyse söz konusu aşka talip olan bireyin davranışları libido kavramıyla açıllanamaz. Böyle bir yaklaşım Ayverdi’nin romanlarını anlamsızlaştırır.

Ateş Ă̆acl, Ayverdi'nin diğer eserlerine nazaran kurgusu daha zayıf bir eser olmakla birlikte mesnevi geleneği ile modern roman arasında bağ kurması bakımından dikkate değerdir. Eserde Ayverdi, Cemil ve Juliette karakterleri üzerinden Doğu-Batı meselesine dair düşüncelerini dile getirmiştir. Juliette, Yaşayan Ölü'deki Leyla ve Batmayan Gün'deki Aliye karakterleri gibi iç âlemine doğru bir yolculuğa çıkmıştır. Yolculuk, Ayverdi'de önemli bir istiaredir. Bu, onun romanlarını bir şehir pikareski biçimine sokar. Fakat bu yolculuklar Mantıku't-Tayr ve Hüsn ü Aşk'taki gibi aslında yerli ve derunidir. Buna ilaveten fiziki bir mekân değiştirme de söz konusudur. Aliye Almanya'ya, Leyla Konya’ya, Juliette ise Bursa'ya gitmiştir. Konya gibi Bursa da tesadüfi bir mekân değildir. Osmanlıdan tevarüs ettiği manevi iklimi Cumhuriyet Türkiye'sine nakleden selatin şehridir. Bursa'da Cemil ile tanışıp ona âşık olan Juliette’in tasviri, “Bursa'da Zaman” şairinin meşhur Nuran'ını hatırlatır: 
Bu ne geniş fihristli bir kitap... Bu ne muvaffakiyetli ve süratli bir atlayış... Kışla yazı, gece ile gündüzü bu ne maharetli birleştiriş, gülerken ve konuşurken, beyaz, muntazam dişlerini şimşek süratiyle ortaya koyan dudakları, en şuh, en hareketli bir kadına ait. Fakat kaşlarının âmir kudreti altına saklanmış gözleri, derin, esrarlı hatta sert denecek kadar mütehakkim ve koyu bir tefekkür îtiyadiyle de dalgın. (Ayverdi, Ateş Ă̆acı, 2011, s. 102).

Juliette, tıpkı Nuran gibi sadece endam ve edasıyla güzel ve şuh değil, aynı zamanda en az onun kadar fetanet sahibidir. Yazar onun için "Şüphe yok ki plastik güzelliği, sun’̂̂lik ve laubalilikle sakatlanmamış zekâsı, fikirleri ve dirâyeti bir mıknatıs kuvveti taşımakta” der (Ayverdi, Ateş Ağacı, 2011, s. 110). Belli ki yazar idealize ettiği kadının hem fiziki hem de fitri kabiliyetiyle müstesna olmasını istemektedir. Fakat bu hilkat şaheseri terbiyesi tamamlanmadan kemale eremez. Juliette'in şu sözleri onun kemalini gösterir:

İnsanlardaki bu bir taraflı çalışma, bu sırf maddîleşme hareketi cemiyetin manevî esaslarını, ahlakını, fazîletini, şuûrunu gün günden silip götürmekte. Ruh ve maddeden mürekkep olan insanın, bir tarafın ziyâde ihmâlinden ve diğer tarafın ziyâde şımartılmasından zarfı mazrûfu mâhiyetini kaybetti. Bizim mazrûfu hırsızın çaldığından haberimiz yok, zarfa her gün biraz daha zînet veriyor, elden ele gezdiriyor yere göğe koyamıyoruz. (Ayverdi, 2011a, s. 113).

Juliette’in söylediği bu söz Ayverdi’nin romanlarındaki espritüel gücün ifadesidir. Yazar, kapitalist dünya düzeninde ilerlemiş Batıya yem olan Cumhuriyet Türkiye'sinin sadece maddi hayatla meşgul olduğunu, fakat bu kabuğun içini dolduracak hiçbir değer üretemediği gibi geçmişten gelenleri de yitirdiğini belirtir. İbrahim Efendi Konağı yazarının romanı az çok bu kaybedişin romanıdır. Ayverdi, hemen bütün romanlarında maddenin manaya üstün tutulmasına şiddetle karşı çıkar. Onun romanlarında bu düşünceyi genellikle münevver insan tipi dile getirir.

Yaşayan Ölü romanı da Ayverdi’nin yine kendisini bulma ümidiyle İstanbul'u terk edip yollara düşen ve Konya'ya yerleşme kararı alan Leyla'nın değişimini anlatır. Eserde Leyla arayan kadını, Ayşe ise o mertebeye ulaşmış kadını temsil etmektedir. Romanın başlangıcında Leyla, maddi bir aşkın acısıyla mustariptir ve arkadaşı Seniye'ye de kocasına âşık olup hiç düşünmeden onunla evlendiği için kızmıştır. $\mathrm{Bu}$ evrede Leyla aklın zincirinden kendisini kurtaramayan, ancak bulunduğu ortamın maddi değerlerinden de haz almayan bir kişi olarak karşımıza çıkar. İstanbul'un riyakâr ve menfaatperest muhitinden kaçıp Konya'ya gelen; ancak burada da aynı felaketlerle karşılaşan Leyla'nın yaşadıkları, Freud'un "aslında insan doğuştan kötüdür" tezini doğrular niteliktedir. Zaten Leyla bu menfi insan tabiatından kaçar. Romanın bir yerinde bunu şöyle ifade eder: "Hoca olmamın psikolojik sebepleri arasında, bütün zevki, kesesinin kuvvetine dayanarak, muhitini kasıp kavuran müstebit, mütehakkim bir büyükannenin nüfuzundan kurtulmak da vardı.” (Ayverdi, 2012, s. 32). Bu sözüne bakarak Leyla'nın irsi bir kompleks taşıdığına hükmedilebilir. Belli ki kahraman, çocukluk döneminde yaşadığı müstebit babaanne baskısından kurtulmak istemektedir. Fakat ölmüş bir büyüğün baskısından kurtulmak için yaşanan mekânı terk etme, psikolojik gerçeklikle ne kadar bağdaşır? Ayverdi karakterlerini inşa ederken onları zorlu bir yolculuğa çıkarır ve bu yolculuk esnasında dönüştürür. Böylece yolculuk zahmetinin terbiye üzerindeki tesirine işaret edilmiş olur. Aynı zamanda muhitinden ayrılmak, bireyi kendi beni üzerinde düşünmeye sevk eder. Nitekim eserin devamında Leyla, "Fakat ben ki hesapsız insan kalabalı̆̆ı arasında olmama rağmen yalnız ve kimsesizdim.” (Ayverdi, 2012, s. 24) diyecektir. Leyla'nın yalnızlı̆̆ Erikson’un geliştirdiği psiko-sosyal kurama göre değerlendirilecek olursa kahramanın genç yetişkinlik 
dönemi ${ }^{3}$ gelişim görevlerini gerçekleştiremediği söylenebilir. Kişisel ilişkiler kurmakta zorlanan Leyla, aradığını bulamamaktan dolayı bulanık bir su birikintisi gibidir. Daha sonra en yakın arkadaşı Seniye'nin kocasına âşık olan Leyla, Gerçek Hattat Çelebi’nin yardımıyla manevi aşkın sırrına ererek durulacaktır.

Yaşayan Ölü’nün bir diğer münevver kadını Ayşe'dir. Leyla, onu örnek alarak nefis tezkiyesini tamamlamaya çalışır. Ayşe, nefs-i emmarenin baskısından kurtulmuş mükemmel bir insandır. Zaruri ihtiyaçlarının dışında kalan hiçbir kıymetle ilgilenmez. Yazar, alçakgönüllü, samimi, ihlaslı, edepli saf ve temiz yürekli kahramanını "hilkat şâheseri" (Ayverdi, Yaşayan Ölü, 2012, s. 142) olarak tavsif eder. O, Batı menşeli psikoloji bilimine göre tanımlanacak olursa Maslow’un kendini gerçekleştirmiş bireyleri kategorisine dâhil edilmelidir.

İnsan ve Şeytan, adından da anlaşlacağı üzere, Ayverdi’nin yine zitlıklar üzerine kurulu eserlerinden birisidir. Eserin kahramanı Şevket’i babası köyünden ve annesinden zorla ayırarak çalışttğı konağa getirmiştir. Konakta herkes tarafından çok sevilen Şevket, Paşa ve hanımı tarafından da çok sevilir ve itinayla yetiştirilir. Nitekim Paşa'nın yeğeni İsmet ile de evlendirilir. İsmiyle müsemma olan İsmet, Ayverdi'nin mükemmel kadınını temsil etmektedir. Şevket karısını şöyle tanıtır:

\begin{abstract}
Karım, hayat sâhamın pürüzlerini temkinli ve bilgili elleriyle düzelten, hazırlayan büyük kadın, benim için bu varlık âleminde en kavî, en kutsî mesnettir. Onun asıl dürüst ve ağırbaşlı şuûru, beni en genç yaşımdan îtibâren sevk ve idâre etmiştir. Karım bir yandan temkinli, irâdeli bir zevce ve iyi bir insan vasfı ile bana ve cemiyete karşı vazîfelerini yaparken, mânevî bir temizlik ile de kendine karşı mükellef olduğu birtakım insanlık borçları bulunduğunu söyler ve hayâtın bin türlü cereyânına, zıt ve muhâlif rüzgârına rağmen, etrâfını, bu sı̆̆ındığı kaleden seyreder ve hiçbir kuvvetle dışarı sürüklenmez (Ayverdi, İnsan ve Şeytan, 2011, s. 11).
\end{abstract}

Her ne kadar kurgunun kendi mantığı içerisinde bir gerçekliği varsa da yukarıdaki cümleler aslında bir kadın yazarın kadın kahramanı için söyledikleridir. Denilebilir ki yazar bu cümlelerle bir kadında görmek istediği meziyetleri ifade etmektedir. Belki bu cümlelerin katarsis teorisiyle de bir ilgisi vardır. Yazar kendisinde görmek istediklerini kahramanıyla gerçekleştirmiş olabilir. Ancak yazarın burada asıl ortaya koyduğu, aile ile cemiyet arasında denge kuran kadının toplumda hayati bir vazife üstlendiği fikridir. Son cümlede geçen "kale" kelimesi tesadüfen seçilmemiştir. Belli ki Ayverdi, İsmet gibi güçlü ve kabiliyetli kadını cemiyet hayatı için iç kale olarak görmektedir. Bu kale hakiki terbiyenin eseridir. Annesi Nazife Hanım'ın zıddı bir kişiliğe sahip olan İsmet ile Ayverdi, bireyin benlik oluşumunda terbiyenin irsiyete üstünlüğunü vurgular. Ancak yazar irsiyetin rolünü inkâr edemez. Şevket’in kızı Güzin’i söylediği şu cümlelerden bile bunu anlamak mümkündür:

Fakat teşekkülât ve çehre itibârı ile babasının bir kopyası olan genç kızın içinde anasının ruh tecellîleri ve aşırı bir hassâsiyet zembereği vardır. Lâkin bu zembereğin karımda olduğu gibi istediği zaman açlan, istediği zaman kapanan uysal ve hesaplı bir mekanizması yoktur. Evet, onda ne anasının hazımlı ve temkinli sükûnunu ne de dayanıklı âsâbını bulmak kâbildir. Çabuk hiddetlenen, çabuk yatışan, çabuk somurtan ve çabuk neşelenen müşkül mîzacı ile bu kız benden ve karımdan da bambaşka bir insandır (Ayverdi, İnsan ve Şeytan, 2011, s. 26).

Erik Erikson, yaşamı sekiz gelişim dönemine ayırır: Oral duyum dönemi, anal kas dönemi, cinsel-devinsel dönem, gizil dönem, erinlik ve ergenlik dönemi, genç yetişkinlik dönemi, yetişkinlik dönemi, olgunluk dönemi. 
Her bakımdan mükemmel olan İsmet'e mukabil kızı Güzin kendine hâkim olmakta sıkıntılar yaşayan birisidir. Şevket, bunu da irsî mülahazalarla izah eder: "Fakat onda yalnız anasının değil, benim de kanım var. Sefil, pis ve kirli kanım...” (Ayverdi, İnsan ve Şeytan, 2011, s. 225).

İnsan ve Şeytan'ın tezi iyi ve kötü kadın, yani İsmet ile Lale üzerine kurulmuştur. Bu sebeple İsmet’i daha iyi anlamak için onun zıddı olan Lale'ye de kısaca bakmak gerekir. Lale şehvet düşkünü maddeci kadının en ileri örneğidir. İstediğini elde etmek için tenini kullanır; laubali, pervasız ve hercaidir. Jung’un arketipsel sembolizmine göre gölge arketipinin baskın olduğunu gördüğümüz Lale, dışa dönük sezgici tip olarak da kabul edilebilir. Nitekim Jung, bu tip için "Genellikle yeni bir şeyin peşinde olduğu zamanlarda öteki insanların duygularına ve inançlarına karşı acımasızdı"” (Fromm, 2012, s. 55) der. Femme fatale özellikleri gösteren Lale, Freud'un kuramına göre ise idin haz ilkesi doğrultusunda yaşamaktadır. Psikanalizm Ayverdi'nin menfi kadın kahramanlarını tahlil etmeye daha muvafiktır. Bu nedenle Lale'nin kişiliği Freud'un söylediklerini doğrular mahiyettedir. Yazar, Lale'nin yaşam ilkesini şu sözüyle küçümser: " 'Eğer nefsin şehveti aşk olmuş olsaydı, eşek ve öküz, âlemde âşıların baş defterine yazılırdı.' diyen büyük insan ne doğru, ne doğru söylemiş.” (Ayverdi, İnsan ve Şeytan, 2011, s. 204). Bu sözü, Freud’un cinsel içgüdü görüşünün reddi olarak da anlamak mümkündür.

Son Menzil'de münevver kadın tipinin iki örneği karşımıza çıkmaktadır: Melek ve Seniha. Melek, anne ve babasını kaybetmiş bir kız çocuğu iken Cemile'nin vesayeti altına girmiştir. Eserin kötü kadını olan Cemile, Melek'in ailesinden kalan paraya el koymak amacıyla ona sahip çımaktadır; ancak gerek ilk eşi Feyyaz, gerekse ikinci eşi Haşim, buna müsaade etmemişlerdir. Cemile'nin bütün kötü niyetine rağmen, enişteleri tarafından çok sevilen ve müdafaa edilen Melek, ilk eniştesi ve sonradan eşi olacak Feyyaz sayesinde manevi dünyasını zenginleştirirken Cemile'nin ikinci eşi olan Haşim sayesinde de resim sanatında kendisini yetiştirmiştir. Melek zor bir çocukluk dönemi geçirmesine rağmen, kişiliği bundan olumsuz yönde etkilenmemiştir. "Çocuk zekî ve vefâkârdı. Bâhusus tenkit ve hüküm hassaları, olgun kimselerin sâhip olabileceği bir idrâke dayanı[r]." (Ayverdi, 2007, s. 122). Ayrıca "Histe ve fikirde bir tâkipçi değil bir pişdar[dır]." (Ayverdi, 2007, s. 73). Nefsine son derece hâkimdir. "Zîra Melek arzularını mantık ve muvâzene ile teftiş ettikten sonra açıklar." (Ayverdi, 2007, s. 73). Ayverdi'nin üstün kabiliyetlerle mücehhez münevveri, aynı zamanda Müslüman Türk gelenek ve göreneklerine derinden bağlıdır. Bir o kadar da tarih şuuru ve millî hassasiyet sahibidir. Tarihî mekânları gezerken gördüğü yeni binaların biçimsizliğini "çıban çıkarmış yüz" (Ayverdi, 2007, s. 46) diye tarif ederken bu hassasiyetle karşılaşırız. Romanın önemli bir bölümü Melek’in kişilik gelişimine ayrılmıştır. Eserin sonunda kendisine manevi babalık yapan eniştesi ile kimseye haber vermeden evlenmesi kişiliği açısından tutarsız görünmektedir.

Romanın bir diğer münevver kadını Seniha, mustarip bir insandır. Bu ıstıraba sevmediği kocası Siret’le evliliği sebep olur. Kendisine yakıştıramadığı kocasıyla sürdürmek zorunda olduğu bu evlilik müşkül bir vaziyettir. Aslında Seniha'yı mutsuz eden bir başka sebep daha vardır. Beraber yetiştikleri yeğeni Haşim'e âşıktır. Fakat Seniha, ahlakıyla telif edemediği aşkını sır olarak saklar. Bu sırla yaşamak zorunda kalan Seniha'nın çok başarılı bir aktör olması yüceltme mekanizmasıyla açıklanabilir. Freud'a göre yüceltme mekanizması başarılı savunma mekanizmalarındandır. Bu mekanizma "egonun boşalımı engellemeksizin ulaşılmak istenen amacı değiştirmesi” olarak tanımlanır (Gençtan, 2014, s. 88). O hâlde bu durumu, Seniha'nın duyduğu büyük aşktan gelen enerjinin ego tarafindan oyunculukla boşaltılması şeklinde açıklayabiliriz. Güzel, zengin, kültürlü bir kadın olan Seniha aynı zamanda iyi niyetli, anlayışl, muhafazakârdır. Bu özelliklerine baktığımızda, diğer romanlardaki ideal kadınlar gibi, Son Menzil'deki Melek ve Seniha'nın da Jung'un öğretisinde bireyleşmeyi sağlamış, Maslow'un hiyerarşisinde ise kendini gerçekleştirmiş kişiler olduğu anlaşılmaktadır. Ancak daha önce de belirtildiği üzere Samiha 
Ayverdi'nin romanlarındaki münevver kadınların psikolojilerini tahlil ederken psikanalizmin yetersiz kaldığı görülür. Zira bu kadınların kişiliklerini tayin eden asıl saik içgüdülerinden ziyade millî ve manevi terbiyeleridir. Son Menzil, Samiha Ayverdi'nin Freud'u aleni biçimde eleştirdiği bir eser olması bakımından ayrıca önem arz etmektedir. Okçu Bahaeddin aracılığıyla Freud'a itiraz ederken şunları söyler:

Budala adam [Freud], her canlı mahlûkun mayasına konmuş olan nesil sürükleyici kuvvete aşk diyecek kadar budala! Cinsî temâyüllere aşk demenin, koruğa üzüm demekten ne farkı var? Sonra da zavallı insanlar en asil duygularına edilen bu iftirâları kabûle savaşırlar. Ne yapsınlar ne yapsınlar, daha doğrusunu, daha berrak daha hâlisini görmemişler ki... (Ayverdi, 2007, s. 146).

Samiha Ayverdi aynı zamanda mütefekkir bir yazardır. Dolayısıyla insanı içgüdüleriyle izah etmeye çalışan psikanalizmin karşısına daha güçül bir teoriyle çıkamamanın ıstırabını duymaktadır. Yukarıda yer verilen cümlelerde cinsel içgüdünün kişiliğin ekseni sayılmasına itiraz eden Ayverdi, Freud ve takipçilerinin, sufizmi ve ilahî aşkı bilmediklerini düşünmektedir. Romanın devamında kahramanlar psikoloji biliminin kurucusundan bahsederken Ali Feyyaz, yazarın düşüncesini yansıtan şu cümleleri sıralar: "Evet bir Freud gelir, evvelce bilinenleri tahrip eder; belki o da nazariyesinde haklıdır; zîra aşk ismini verdiği kuvvet kendi bildiği aşktır. Zavallı adam, zamâna ve mekâna tasarruf eden, daha doğrusu yaratılışın mûcidi olan aşkı ne bilsin?” (Ayverdi, 2007, s. 147). Bu cümleler iki medeniyetin zihniyet farkını da ortaya koyar. Freud, teorisini geliştirirken Batı insanını gözlemlemiş ve vardığı sonucu bütün milletlere ve bütün coğrafyalara teşmil etmiştir. Bu teorinin tasavvuf kültürüyle yetişmiş Müslüman bireyleri ihata edemediği açıktır. Yukarıdaki cümlelerin yazarı Ayverdi’nin belirtmek istediği de bu olmalıdır.

Yolcu Nereye Gidiyorsun'da münevver kadınların başında Adli’nin büyük annesi gelmektedir. Büyük anne klasik Türk kültürüyle yetişmiş bir kadındır. Yazar onu oğlunun gözünden değerlendirirken "O sizin bildiğinizden çok cesur ve büyük bir kadındır.” der. (Ayverdi, 2009, s. 327). İçinden geldiği medeniyetin hakiki bir temsilcisi olan büyük anne ortaya koyduğu kişilikle sonraki nesilleri de hayrette bırakır. Torunu Adli, onu tek cümleyle tanıtır: "Şu büyük annem insan kadındır vesselâm." (Ayverdi, 2009, s. 123). Bu basit tanım önemli bir kavrama işaret eder: "insan kadın". Tasavvuf öğretisinde inanmayan ve nefsani arzularına göre yaşayan insan hayvan kabul edilir. Niyâzî-i Mısrî bu düşünceyi ifade eden mısralarında şunları söyler:

Savm u sâlât u hac ile sanma biter zâhit işin

İnsân-ı kâmil olmaya lâzım olan irfân imiş

Kande gelir yolun senin ya kande vartr menzilin

Nerden gelip gittiğini anlamayan hayvân imiş

(Niyâzî-i Mısrî, 2015, s. 538)

Bu beyitleri şerh eden Mehmed Efdal Emre, "Tevhidde üç türlü insan vardır.” dedikten sonra bunların ilki olan insân-ı hayvânı şöyle izah eder: "Yaşayan insan. Allâh’ı bilmez, hak hukuk bilmez, tevhîd girmemiş, sûreti insan olan.” (Niyâzî-i Mısrî, 2015, s. 540). Bu durumda Niyâzî-i Mısrîye göre hak dine inanmayan Batı insanı insân-ı hayvân'dır. Öyleyse Freud bu insanın kişiliğini cinsel içgüdü ile izah ederken hiç farkında olmadan İslam sufilerine yaklaşmaktadır. Bir mutasavvıf olan Samiha Ayverdi'nin yukarıdaki itirazı da Freud'un teorisini bütün insanlığa teşmil etmesinedir. Yoksa Ayverdi’nin 
romanlarındaki inançsız kahramanlar da haz ilkesine göre yaşarlar ve kişilik gelişimleri psikanalizmin verileriyle tahlil edilmeye müsaittir. Ancak aynı insanlar inanmaya başlarlarsa iş değişir.

Yolcu Nereye Gidiyorsun'daki diğer entelektüel kadın Madam Faguet’tir. Sonradan Müslüman olan Madam, imanın insan üzerindeki müspet tesirini gösterir. Kendi millî değerlerinin farkında olmayan ve bu değerleri acziyet olarak gören Nemide'nin yanında Madam Faguet, başka bir milletin geleneğine ilgi duyması, bu geleneği "Doğru ve esâsından araştırmış." (Ayverdi, 2009, s. 254) olması sebebiyle ciddi bir münevverdir.

Eserin başında kimsesiz ve cahil bir kız olarak büyük annenin konağına getirilen Mecbure, Adli'nin yardımıyla yetişir. Adli, Mecbure'nin "mâsum, basit, işlenmemiş varlığına" (Ayverdi, 2009, s. 160) ilgi duyduğundan onu edebiyatla geliştirmek ister. Bu durumu Maslow’un ihtiyaçlar hiyerarşisi ekseninde değerlendirirsek Mecbure'nin bilme-anlama basamağında olduğunu söyleyebiliriz, ancak belirtmek gerekir ki onda öteki münevver kadınların bilim ihtirası yoktur. Adli'nin dikkatiyle Mecbure'yi tahlil eden yazar, şu tespitlerde bulunur:

Bu kıza ne Jale'nin sınıfının tereddîsinden bir leke, ne de Fahrünnisâ'nın kat'̂̂, ölçülü mefkûreciliğinden, erkekleşmiş bir inat sinmişti. Evet, o ne Jale gibi memleketin başına bir parazit kesilerek Avrupâî görüşüyle yabancılaşmış, fantazileşmiş, ne de Fahrünnisâ gibi, avukat olmak, doktor olmak, çalışmak hevesiyle kadınlığından fedâkârlık etmek isteyen sınıftandı. O, sapsâde, fakat cinsinin insiyakları ile etrâfına faydalı, katışıksız ve yapmacıksız bir koldandı. Belki göze görünür seçkin bir vasfı yoktu. Fakat o, meziyet ve fazîlet denen mânevî imtiyazları, istediği, îcap ettiği zaman içinin derinliklerinden bulup istifâde etmesini ve ettirmesini bilenlerdi. Bu kız benim görüşüme göre, işlenmemiş, ayak basmamış, vahşî bir ülke idi ki, dâima yaratıldığı gibi kalacak, kimse tarafından keşfedilemeyecekti. (Ayverdi, 2009, s. 227).

Saflığı, sadeliği ve sağduyusuyla Mecbure, çevresi için sakin bir sığınak kadar güven vericidir. Münevver bir hanımefendi kadar “zarif ve selim zevklere sahip”tir (Ayverdi, Yolcu Nereye Gidiyorsun, 2009, s. 293). Sevmek ve sevilmek istidadına malik olan Mecbure nihayet âşık da olur. Ancak aşkına karşılık göremeyeceğini düşündüğünden bu aşkı, tıpkı Seniha gibi, sır olarak saklar ve kendisine aynı aşkla bağlı olan Adli ile evlenmeyi kabul eder. Mecbure'nin aşkını gizleyip Adli'yi sevmeye çalışması bastırma ve yadsıma mekanizmalarıyla açıklanabilir. Çünkü "Bazı insanlar zorlanma sonucu içine düştükleri sıkıntılı durumlarda, her işleri yolunda gidiyormuşçasına davranma eğilimi göstererek kendilerine ve çevrelerine karşı mutsuzluklarını belli etmezler.” (Gençtan, 2014, s. 77). Dolayısıyla Mecbure'nin davranışları, psikolojisine uygun kurgulanmıştır.

Mecbure'nin muhafazakârlı̆̆ı klasik kültüre olan aşinalığı ile tezahür eder. Adli, bu durumu şöyle anlatmaktadır:

Yenilerden pek hoşlanmaz, Hâmid’i beğenir fakat hem ağır hem de biraz yabancı bulur. Şehâbeddin'in bâzı şiirlerinde, natürmort bir tablo seyreder gibi zevk alırdı. Eskilerden Yûnus'un mâverâ rüzgârı getiren sıcak sesi, Nedîm'in kuvvetli, pervâsız edâsı üstünde sık sık durur, bilhassa Fuzûli, coşkun ve dalga dalga hassâsiyetle onu büyülerdi. (Ayverdi, 2009, s. 408).

Mecbure'nin zevki yerlidir, yukarıdaki cümleler yerli bir şiir zevkinin küçük bir hülasası sayılır. Bu nedenle kahramanın Samiha Ayverdi'yi temsil ettiği söylenebilir. Ayverdi, kahramanı üzerinden yerli zevk ve terbiyeyle yetişen kadının ne kadar sakin ve tabii olduğunu da ortaya koymuştur. O, dışarıdan 
bir beklentiyi karşılamak için değil, kendisi için öğrenir. Bu, aynı zamanda ananevi terbiye biçimidir. Binaenaleyh örgün bir eğitim almadan münevver bir kadın olması yadırganmamalıdır.

\section{Sonuç}

Samiha Ayverdi'nin romanlarındaki münevver kadınlar mütedeyyin ve muhafazakârdır. Ananevi terbiye ile yetiştiklerinden dirayetli ve sağlam karakterlidirler. Kusursuz kişilikleriyle idealize edilen bu kadınlar güzel sanatlara da yatkındır. Aliye resme ilgi duyar ve piyano çalar, Juliette tarihe ve tarihî eserlere meraklıdır; Ayşe tezhip sanatçısı, Melek ressam, Seniha tiyatrocudur. Özellikle Mevlevilik olmak üzere bazı tarikatların klasik sanatları ve onların enstrümanlarını birer terbiye aracı olarak kullandıkları bilinmektedir. Her bakımdan birer "hilkat şaheseri" olarak kurgulanan bu münevver kadınlar sanatın büyülü gücüyle de ikmal edilmişlerdir. Böylece aslında sınırlı olan beşerî hayatları da zenginleştirilmiştir. Yozlaşan hayatın ortasında kendi kendilerini muhafaza için kabuklarına çekilmek zorunda kalan bu zarif ve kabiliyetli insanların sanatla meşgul olmaları psikolojik gerçekliklerine de uygundur.

Samiha Ayverdi’nin idealize ettiği kadınlar aslında istisnai tiplerdir. Dolayısıyla yaşadıkları zamana ve özellikle de ananevi hayattan uzaklaşmış kadınlara göre fevkalade şahsiyetlerdir. Kişiliklerinin oluşumunda nefis terbiyesi belirleyicidir. Bu sebeple onların karakterlerini psikanalizmin verilerine göre çözümlemeye çalışmak genellikle mümkün değildir. Eğer kişilik gelişimleri mutlaka psikoloji bilimine göre çözümlenecekse onları Jung'un "bireyselleşmeyi sağlamış kişileri” veya Maslow’un "kendini gerçekleştirmiş bireyleri" kategorilerine dâhil etmek mümkündür. Ancak bu kategoriler de onların kişiliğini tam olarak karşılamaz. Bu nedenle Ayverdi’nin münevver kadınları günümüz okuruna gerçekçi görünmez. Aslında bu durum yazarın bilinçli bir tercihidir. Ayverdi okurun önüne bu ideal insanları koymak suretiyle onda tasavvufa karşı bir ilgi uyandırmak istemiştir. Beşerî terbiyeyle ilgili herhangi bir sistemin niteliği yetiştirdiği insan unsurunun keyfiyetiyle ölçülür. Yazar, bu mümtaz insanları ortaya koymakla onu yetiştiren terbiye sistemine dikkati çekmektedir. Dahası modern psikolojide kişilik gelişiminin kaynağı olarak gösterilen içgüdü ve komplekslere karşılık terbiye unsurunu öne çıarmaktadır. Yazara göre bugünkü psikoloji ilmi Müslüman Türk insanının kişiliğini izah etmekte yetersizdir. Onu tanıyabilmek için bu coğrafyada asırlarca yaşamış olan terbiyeyi dikkate alan bir başka ilme ihtiyaç vardır ki çalışmamızda değerlendirmiş olduğumuz ilm-i nefs bunlardan biridir. Bu nedenle Ayverdi’nin münevver kadınlarını klasik İslam düşüncesindeki ilm-i nefs teorisine göre değerlendirmek gerekir.

Roman sanatında yazar, kendi adesesinde geçirdiği bir toplum tasavvuru anlatır. Kullandığı en geniş̧ malzeme kendi dünyasıdır. Ayverdi'nin münevver kadınları az çok kendisini yansıtır. Bu kadınların hem kendilerini kuşatan bozulmuş dış dünya ile hem de nefisleriyle mücadele ettikleri görülür. Çevrelerine uyum sağlayamamaları ve ilk okuyuşta gerçekçi görünmemeleri bundan ileri gelmektedir.

Netice olarak Samiha Ayverdi’nin, romanlarında okur karşısına pedagojik kaygılarla çıktığını kabul etmek gerekecektir. Cumhuriyet Dönemi'ndeki kültür ve ahlak tahribatına yakından şahit olan yazar, yeni nesil Türkiye'sine kendi şahsi tecrübesiyle birleştirdiği alternatif kadın münevverler sunar. Ananevi terbiye ile yetişmiş bu kadınlar rol model olarak kurgulanmışlardır. Modern insanın kaprislerinden arındıkları için psikolojilerini modern psikanalizmle izah etmek zordur. Böylece yazar, Cumhuriyet Dönemi Türk edebiyatına, ekseninde mütedeyyin, muhafazakâr ve münevver kadınların yer aldığı medeniyetimizin irfanına layık yerli bir romancılık teklif eder. Şüphesiz sağlam bir dil ve üslupla birlikte. 


\section{Kaynakça}

Adler, A. (2014). İnsanın Doğasını Anlamak. (D. Başkaya, Çev.) İzmir: İlya.

Ayverdi, S. (2006). Küplücedeki Köşk (2 b.). İstanbul: Kubbealtı.

Ayverdi, S. (2007). Son Menzil (3 b.). İstanbul: Kubbealtı.

Ayverdi, S. (2009). Yolcu Nereye Gidiyorsun (4 b.). İstanbul: Kubbealtı.

Ayverdi, S. (2010). Batmayan Gün (6 b.). İstanbul: Kubbealtı.

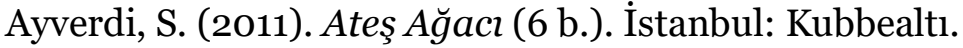

Ayverdi, S. (2011). Insan ve Şeytan (6 b.). İstanbul: Kubbealtı.

Ayverdi, S. (2012). Yaşayan Ölü (6 b.). İstanbul: Kubbealtı.

Bahadır, A. (2010). Jung ve Din. İstanbul: İz.

Buharî, İ.-1. (2014). Sahîh-i Buharî Muhtasar. (H. Aldemir, İ. Tüfekçi, O. Güman, İ. Aktepe, M. Eryarsoy, \& M. Odabaşı, Çev.) İstanbul: Karınca-Polen.

Burke, E. (2017). Devrimin Şeytanlart. (Ö. Koyuncu, Çev.) İstanbul: Tefrika.

Demirci, M. (2007). Samiha Ayverdi'de Iman ve Tasavvuf. TKKD Altay Kültür Sanat ve Eğitim Vakfı Panel Tebliğ Metinleri: TKKD Altay Kültür Sanat ve Eğitim Vakfı.

Devellioğlu, F. (2015). Osmanhca-Türkçe Ansiklopedik Lûgat. Ankara: Aydın.

Fromm, E. (2012). Psikanaliz ve Din (3 b.). (E. Erten, Çev.) İstanbul: Say.

Gençtan, E. (2014). Psikanaliz ve Sonrası. İstanbul: Metis.

Karaman, H., Özek, A., Dönmez, İ., Çağrıcı, M., Gümüş, S., \& Turgut, A. (Dü). (2006). Kur'ânı Kerîm ve Açıklamalı Meâli (15 b.). Ankara: Türkiye Diyanet Vakfı.

Köksal, M. A. (2011). Peygamberler Tarihi (15 b.). Ankara: Türk Diyanet Vakfı.

Köse, A. (2011). Freud ve Din (3 b.). İstanbul: İz.

Kubbealtı Lugati. (2018, Ocak 1). http://www.kubbealti.org.tr: http://lugatim.com adresinden alındı

Niyâzî-i Mısrî. (2015). Dîvânı ve Şerhi (4 b.). (M. E. Emre, Dü.) İstanbul: Gelenek.

Özel, M. (2017, Nisan). Şeytan Aldı Götürdü. Dergâh(326), 12-13.

Saîd Havva. (1990). El-Esâs fi't-Tefsîr (Cilt 5). (M. B. Eryarsoy, Çev.) İstanbul: Şamil.

Snowden, R. (2011). Freud Kilit Fikirler. (M. İnan, Çev.) İstanbul: Optimist.

Tanpınar, A. H. (1998). Edebiyat Üzerine Makaleler (5 b.). (Z. Kerman, Dü.) İstanbul: Dergâh.

Tuzak, U. (2009). Samiha Ayverdi. T. Bora, \& M. Gültekingil içinde, Modern Türkiye'de Siyasi Düşünce (s. 248-260). İstanbul: İletişim.

Türkçe Sözlük (11 b.). (2011). Ankara: TDK.

Türkçe Sözlük I. (1944). İstanbul: Cumhuriyet. 